\title{
A striking new species of Anolis lizard (Squamata, Iguania) from Panama
}

\author{
Erik Hulebak ${ }^{1}$, Steven Poe ${ }^{1}$, Roberto Ibáñez ${ }^{2-4}$, and Ernest E. Williams ${ }^{5}$ \\ 1 Department of Biology and Museum of Southwestern Biology, University of New Mexico, Albuquerque, NM, 87131, \\ USA. Emails: ehulebak@unm.edu, anolis@unm.edu. \\ 2 Smithsonian Tropical Research Institute, Unit 0948, APO AA 34002, USA. E-mail: ibanezr@si.edu. \\ 3 Círculo Herpetológico de Panamá, Apartado 0824-00122, Panamá, Rep. de Panamá. \\ ${ }^{4}$ Departamento de Zoología, Universidad de Panamá, Panamá, Rep. de Panamá. \\ 5 Museum of Comparative Zoology, Harvard University, Cambridge, MA, 012138, USA. Deceased.
}

\begin{abstract}
A striking new species of Anolis lizard (Squamata, Iguania) from Panama. Here we describe a new Anolis lizard from Panama. The new form is most similar to South American Anolis mirus and Anolis parilis but differs in characters of color pattern and scalation. The new species appears to be a close relative of other large mainland Alpha Anolis (latifrons group; “Dactyloa”).
\end{abstract}

Keywords: Squamata, Iguania, Anolis kunayalae sp. nov., systematics, Panama.

\begin{abstract}
Resumen
Una especie nueva y llamativa de lagartija Anolis (Squamata, Iguania) de Panamá. Aquí describimos una especie nueva de lagartija Anolis de Panamá. Esta forma nueva es más similar a Anolis mirus y A. parilis de América del Sur, pero difiere en caracteres del patrón de color y de escamas. La especie nueva parece ser un pariente cercano de otras Anolis Alfa grandes de tierra firme (grupo latifrons; Dactyloa).
\end{abstract}

Palabras clave: Squamata, Iguania, Anolis kunayalae sp. nov., sistemática, Panamá.

\section{Introduction}

The distinctive species A. mirus was described from a single specimen with the locality "Rio San Juan Colombia” by E. E. Williams (1963). Later Williams (1975) described A. parilis, a close relative of $A$. mirus, based on a single specimen from "Rio Baba, $2.4 \mathrm{~km}$ S Sto Domingo de los Colorados, Pichincha, Ecuador”. These species share a unique morphology of the fourth toe, including few lamellae, indistinct toepad, and an especially large claw (see Figure 1 of Williams 1963). Recent fieldwork near El Copé,

Received 13 December 2006.

Accepted 10 May 2007.

Distributed June 2007.
Panama has provided multiple specimens of a striking Anolis possessing this same toe morphology but differing from $A$. mirus and $A$. parilis in color pattern and other characteristics. Here we describe this form from moderate elevations in central Panama as a new species.

\section{Material and Methods}

We consider species to be evolutionary lineages (Simpson 1961, Wiley 1978), and operationalize this concept by identifying species based on consistent differences between populations (Frost and Kluge 1994). That is, we hypothesize that populations that are diagnosable by major differences in the 
frequencies of traits are distinct evolutionary lineages, or species (Wiens and Servedio 2000).

Measurements were made with digital calipers to the nearest $0.1 \mathrm{~mm}$. Snout to vent length (SVL) was measured from tip of snout to anterior of cloaca. Head length was measured from tip of snout to anterior of ear. Head width was measured at the posteroventral corners of the jugal. Femoral length (FL) was measured from midline of body to knee. Ear height (EH) was measured vertically on the ear. Scale terminology follows Williams et al. (1995). Osteological terminology follows Etheridge (1959) and Poe (1998). We compared specimens of the new species to holotypes of probable close relatives (Anolis mirus - University of Illinois Museum of Natural History [UIMNH] 82901; Anolis parilis - British Museum of Natural History [BMNH] 1910.7.11.5).

\section{Species Description}

\section{Anolis kunayalae sp. nov.}

(Figures 1-4)

Holotype - Museum of Southwestern Biology (MSB) 72605 (adult male) collected along the trails of Parque Nacional General de División Omar Torrijos Herrera, 5 km north of El Copé, Coclé Province, Panama ( $8^{\circ} 40.315$ ' N, 80³5.518' W), by Steven Poe, Erik Hulebak, and Heather MacInnes on August 5-8, 2004.

Paratypes - MSB 72603 (hatchling female) and MSB 72604 (sub-adult female), collected in same locality as holotype by Steven Poe on December 24-25, 2003; MSB 72606 (hatchling female), POE 1622 (juvenile female), MSB 72607 (adult male), MSB 72608 (adult female), collected in same locality as holotype by Steven Poe, Erik Hulebak, and Heather MacInnes on August 5-8, 2004; MSB 72609 (adult male, skeleton), same locality and collectors on August 10, 2004; MSB 72610 (sub-adult male), same locality and collectors on August 3, 2005; MSB 72611 (adult female), same locality, collected by Steven Poe on September 14, 2005;
MSB 72612 (adult male), same locality and collector on September 14, 2005; MSB 72613 (adult male), same locality and collector on September 15, 2005; MCZ 185295, same locality and collector on September 16, 2005; MSB 72614 (hatchling female), same locality and collector on September 18, 2005; Círculo Herpetológico de Panamá (CHP) 4513 (adult male), collected in Cerro Bruja, Provincia de Colón (9²7’31” N, 79³4’28” W), by Iván Domínguez on January 27, 1997; CHP 5505 (adult male), same locality as MSB 72604, collected by Karen Lips on July 3, 2002; CHP 5880 (sub-adult male), same locality as holotype, collected by Karen Lips June 2, 2004; MVUP 1721 (adult female), collected at a stream northeast of the sawmill, north of El Copé, Coclé Province, Panama ( $8^{\circ} 40^{\prime} 05^{\prime}$ N, 80³5’33” W) by César Jaramillo, Fidel Jaramillo, Roberto Ibáñez and Fernando Crastz on February 7, 1981; USNM 521924 (adult male) collected at Nusagandi, Comarca de San Blas or Kuna Yala, Panama, (9²0’28” N, 7859’39” W), by Kyle Summers on September 1, 1991.

Etymology - The name Anolis kunayalae gives homage to the native Kuna Yala people of Panama and refers to the locality of one of the paratype specimens.

Diagnosis - Anolis kunayalae, A. mirus and A. parilis are the only Anolis with a unique fourth toe that includes: a narrow toe pad (Norops condition), reduced number of lamellae under phalanges ii and iii of the fourth toe relative to SVL (12-15; Williams 1963: Table 2 ), and distal phalanx (including claw) longer than phalanges ii and iii combined (see Figure 1 of Williams 1963). Anolis kunayalae differs from $A$. mirus and $A$. parilis in dorsolateral pattern of preserved males (A. kunayalae: dark brown with small white posteriorly directed diagonal stripes and ocelli; $A$. mirus: dark brown with indistinct oblique rows of small light dots on sides of body; A. parilis: red-brown with a narrow black middorsal line and black mottling tending to transverse banding on side of neck 


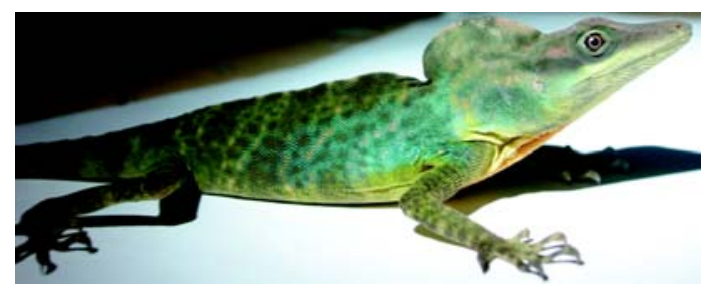

Figure 1 - Male Anolis kunayalae sp. nov.

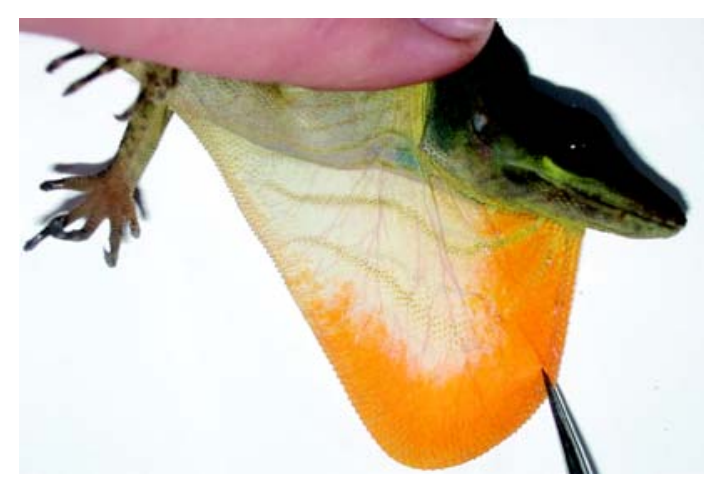

Figure 2 - Dewlap of male Anolis kunayalae sp. nov.

and lower flanks). Anolis kunayalae further differs from $A$. mirus in possessing smooth ventral scales (keeled in $A$. mirus) and scales around the interparietal gradually enlarged relative to temporals and dorsals (abruptly enlarged in A. mirus). Anolis kunayalae further differs from $A$. parilis in possessing two slightly projecting, enlarged, conical to triangular, keeled middorsal scale rows in males (middorsals smooth in A. parilis) and a distinct temporal line of scales (indistinct in A. parilis). Anolis kunayalae also may be distinguished by its extraordinarily prominent nuchal crest in some males (Figure 1). This trait is not present in preserved A. mirus and A. parilis but we cannot be certain that these species do not possess a distendable nuchal crest in life.

Description of Holotype (paratype variation in parentheses, hatchlings not included) - Snout to vent length $95.4 \mathrm{~mm}(81.0-109.3 \mathrm{~mm})$; head

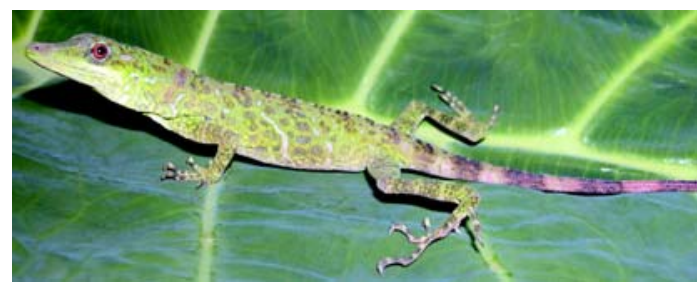

Figure 3 - Female Anolis kunayalae sp. nov. (note enlarged claw on $4^{\text {th }}$ toe).

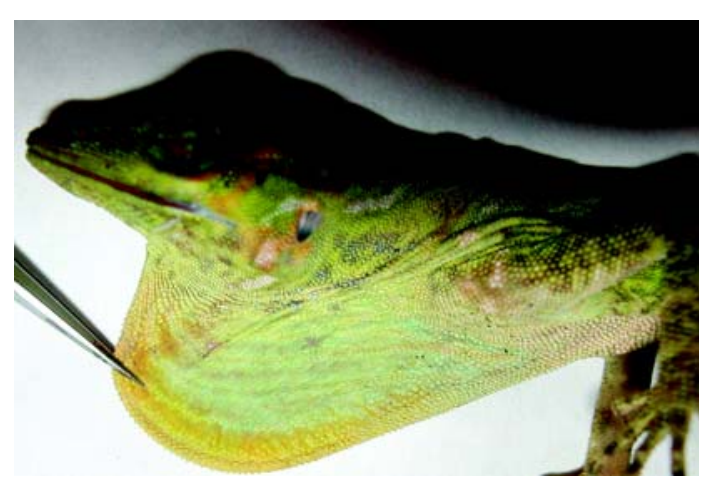

Figure 4 - Dewlap of female A. kunayalae sp. nov.

length $25.1 \mathrm{~mm}$ (21.1-27.9 mm), width $15.1 \mathrm{~mm}$ (12.3-17.8 mm); ear height $1.9(1.9-3.0 \mathrm{~mm})$; femoral length $26.6 \mathrm{~mm}(20.5-30.0 \mathrm{~mm})$; tail length $221 \mathrm{~mm}$ (160-253 mm).

Overall appearance is stout, with robust limbs and broad body; large nuchal crest (present or absent); dorsal head scales mostly smooth but keeled anteriorly; weak frontal depression; 15 (12-17) scales across snout between second canthals; 4 (4-5) scales between supraorbital semicircles; 1 (0-1) slightly elongated supercilliary scales followed posteriorly by several small scales; 9 (6-9) loreal rows; circumnasal separated from rostral by one scale; interparietal length $1.2 \mathrm{~mm}(0.8-$ 1.8); 4 (3-6) scales separating interparietal and supraorbital semicircles; 8 (8-10) supralabials to center of eye; 1 ( $0-1$, majority contact) row of scales separate suboculars and supralabials; 7 (6-8) postmentals; 7 (6-9) postrostrals; scales in supraocular disc about equal in size; mental is 
concave posteromedially, partially divided, even with rostral laterally (extending posterolaterally beyond rostral in most specimens); 2 (1-4) sublabials enlarged along infralabials; large dewlap reaches posterior to axillae in males, with 4-5 (4-6) rows of scales, each row of scales two to four scales wide (smaller in female paratypes); two slightly enlarged postcloacal scales (absent in females, present in males).

Dorsal scales granular and separated, with 2 middorsal scale rows slightly projecting, enlarged, triangular to conical, and unicariate, 9 scales (9-11) counted longitudinally in 5\% of SVL; flank scales granular and separated or juxtaposed; ventral scales smooth and juxtaposed to subimbricate, 10 (8-13) scales in $5 \%$ of SVL, in transverse rows.

Dorsal limb scales distal from the knee and along the anterior of the femur are unicarinate and subimbricate, posterior scales smaller and granular along femur, supradigitals and heel multicarinate; narrow toepads, not distinct; 12 (11-15) lamellae under second and third phalanges of fourth toe, distal phalanx longer than phalanges ii and iii combined; fourth toe reaches beyond eye when hindleg pressed against body; tail with keeled scales and a double middorsal row grading into a single row posteriorly.

Skeletal description (based on MSB 72609 and MSB 72611) - Parietal roof flat, V-shaped, without casque, lacking crenulation on edges, anterolateral corners reach posterolateral corners of frontal; pineal foramen at parietalfrontal suture; slightly rugose on dorsal of skull bones; postfrontal present; frontal sutures anteriorly with nasals; slight longitudinal crests on nasals; external nares bordered posteriorly by nasals; dorsal aspect of jugal terminates on lateral surface of postorbital; no jugalsquamosal contact; posterovental corner of jugal is anterior to posterior edge of jugal; epipterygoid contacts parietal; pterygoid and palatine teeth absent; lateral edge of vomer is smooth; maxilla extends posteriorly beyond ectopterygoid; no basipterygoid crest; no lateral shelf of quadrate; black pigment present around pineal foramen but not on majority of dorsal surfaces; nasals flush with premaxilla, not overlapping; posterior dorsal surface of skull flat, not angled inferiorly; mandibular toothline extends posterior to anterior mylohyoid foramen; angular process of articular present, large; posterior suture of dentary pronged; anteriormost aspect of posterior border of dentary even with mandibular fossa on one side, anterior to fossa on other; splenial present; ventral aspect of anteromedial process of coronoid extends anteriorly; external opening of surangular foramen entirely within surangular; labial process of coronoid present; coronoid does not extend posterolaterally beyond surangular foramen; no jaw sculpturing; no angular.

Five postxiphisternal ribs, all attached to dorsal ribs (5:0 rib formula), three sternal and two xiphisternal ribs (see Etheridge 1959: Figure 4d); caudal vertebrae with posterolaterally directed transverse processes anteriorly, gradually lost posteriorly (Alpha condition); interclavicle in contact with medial $80 \%$ of clavicle, free at distal end (“arrow shaped”); 23 presacral vertebrae; 3 lumbar vertebrae; autotomy septa not evident on caudal vertebrae.

Color in life of male (from field notes and photos in life) - Dorsum green; flanks and sides of neck aqua blue with thin broken yellow-green or white lines within; reddish brown on dorsum of head; reddish brown spot posterior to eye; iris reddish-brown; eyelid blue-green; throat black with tan tongue and white along edges of mouth; chin, upper and lower lips pale greenish-yellow, dewlap skin white with green tint proximal and orange along anterior border, with multiple rows of yellow-green or blue scales; midventer greenish-white; ventral surface of hindlegs greenish-white; tail green with brown-black bands; alternating tones of green-yellow and dark green bands visible on anterior of limbs and digits; yellow-green under skin folds at front shoulder; alternating tones of dark green and green-yellow along middorsal. 


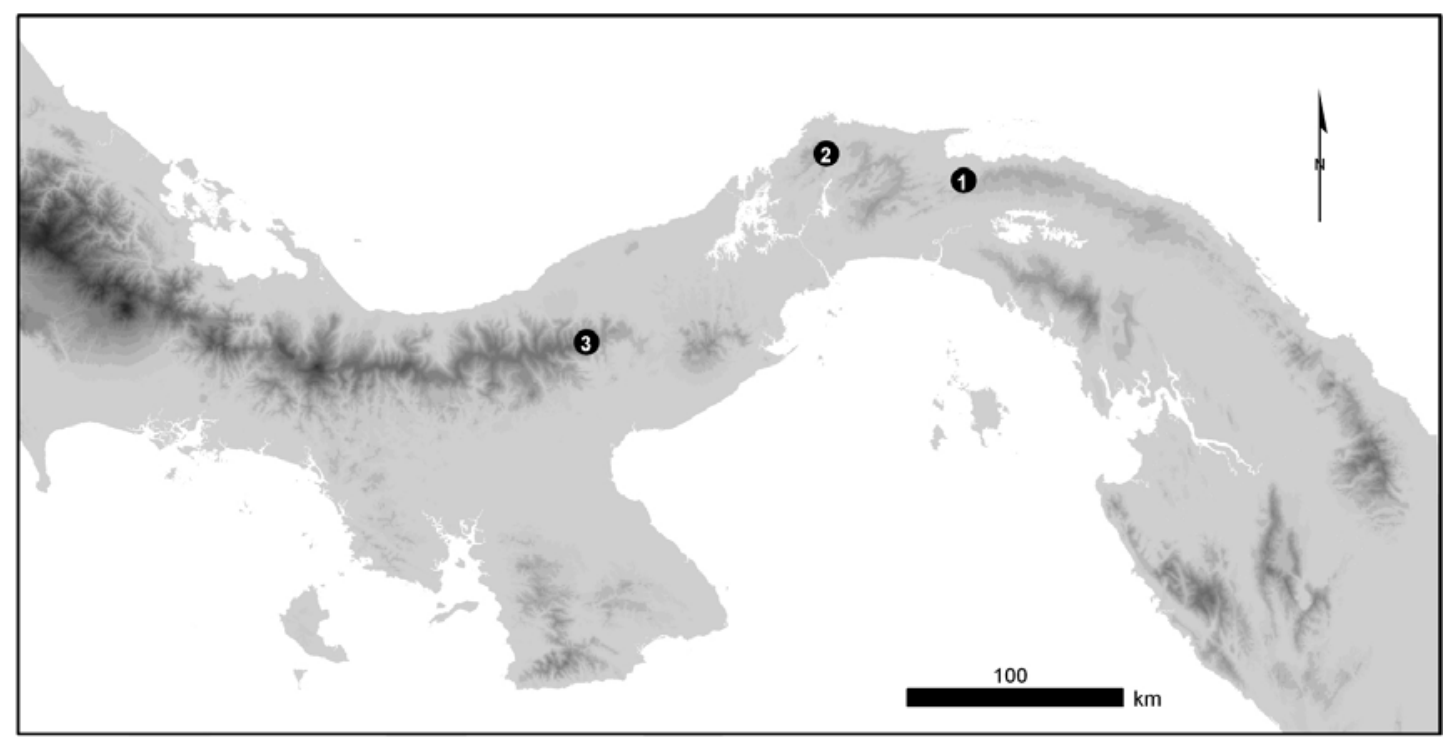

Figure 5 - Distribution of Anolis kunayalae sp. nov.: (1) Nusagandi, (2) Cerro Bruja, and (3) north of El Copé, Parque Nacional General de División Omar Torrijos Herrera.

Color in life of female (from field notes and photos in life) - Coloration of females is very different from males (Figure 2), which may initially lead one to believe these lizards are not the same species. Female dorsum overall lighter green than male, solid or broken white bands traverse flanks and neck along with black or black with green-centered ocelli, creating alternating patterns of black, green, and white along middorsal rows, smaller blue and bluewhite ocelli are also present; anterior dorsum of head reddish-brown; iris red; eyelid white, blue, and green; throat black with tan tongue and white along edges of mouth; chin, upper and lower lips pale green to greenish-yellow; female dewlap yellow-orange border with multiple scale rows of similar color and white skin with a blue-green tint (Figure 4); midventer greenishwhite; alternating tones of green-yellow and dark green bands present on anterior of limbs and digits; tail green with dark brown-black bands. Hatchling females are identical in color pattern to female adults, including dewlap color.
Habitat and distribution - The new species is known from three moderate elevation sites in central Panama: Nasagundi (at 370 m elevation) in Kuna Yala, Cerro Bruja (at 800 m elevation) in Colón Province, and Parque Nacional General de División Omar Torrijos Herrera (at 744 m elevation) in Coclé Province (Figure 5).

Most A. kunayalae were collected in primary and secondary wet forest sleeping on twigs or leaves at night 1-3 m high.

\section{Discussion}

Anolis kunayalae is unlikely to be confused with any other Central American lizard due to its unique color pattern (Figures 1-4). The blue anterior wash and dewlap color pattern of males are especially distinctive. Anolis mirus and $A$. parilis are the only species that are morphologically similar to A. kunayalae, and these species are amply distinct from $A$. kunayalae (see diagnosis) and found over 600 $\mathrm{km}$ southeast of its easternmost known locality 
(see Figure 6 of Williams 1975).

The character states of $A$. kunayalae of high inscriptional rib formula (5:0), lack of caudal autotomy, alpha-type caudal vertebrae, presence of splenial, large size, rows of multiple scales on the dewlap, and presence of a double row of dorsal caudal scales are shared by members of a basal clade of large South American Alpha Anolis (Poe 2004) that is informally called the latifrons group sensu stricto (Williams 1976). This group is part of Etheridge's (1959) larger latifrons group, called Dactyloa by Guyer and Savage (1986). Nicholson et al. (2005) included A. kunayalae (CHP 5505, their "New Species 1"; Nicholson, pers. comm.) in phylogenetic analysis of mitochondrial DNA sequences and found it to nest within this group.

The unique morphology of the fourth toe and other shared character states such as extensive lateral skin folds on the neck, large number of scale rows between supraorbital semicircles, and large number of supralabial scales (see Table 1 of Williams 1975) suggest that the closest relatives of $A$. kunayalae are likely to be $A$. mirus and $A$. parilis, which have not yet been included in phylogenetic analysis. We are analyzing these three species in ongoing phylogenetic analyses of Anolis.

\section{Acknowledgements}

We acknowledge the effort of the Republic of Panama for protecting habitat that maintains populations of Anolis that continue to be discovered. Thanks to Caleb Hickman, Heather MacInnes, César Jaramillo, Fidel Jaramillo, Kyle Summers, Karen Lips, Iván Domínguez, and Fernando Crastz for collecting lizards and providing information for use in this manuscript. Thank you to Eric Schaad for review and comments on the manuscript. Thanks to the Smithsonian Tropical Research Institute and the Autoridad Nacional del Ambiente for collecting and export permits (No. SE/A-70-03, No. SE/A-73-05).

\section{References}

Etheridge, R. E. 1959. The relationships of the anoles (Reptilia: Sauria: Iguanidae): an interpretation based on skeletal morphology. Unpublished Ph.D. Thesis, University of Michigan, Ann Arbor, Michigan, USA.

Frost, D. R. and A. G. Kluge. 1994. A consideration of epistemology in systematic biology, with special reference to species. Cladistics 10: 259-294.

Guyer, C. and J. M. Savage. 1986. Cladistic relationships among anoles (Sauria: Iguanidae). Systematic Zoology 35: 509-531.

Nicholson, K. E., R. E. Glor, J. J. Kolbe, A. Larson, S. B. Hedges, and J. B. Losos. 2005. Mainland colonization by island lizards. Journal of Biogeography 32: 929938.

Poe, S. 1998. Skull characters and the cladistic relationships of the Hispaniolian dwarf twig Anolis. Herpetological Monographs 12: 192-236.

Poe, S. 2004. Phylogeny of anoles. Herpetological Monographs 18: 37-89.

Simpson, G. G. 1961. Principles of Animal Taxonomy. New York. Columbia Universtiy Press. 247 pp.

Wiens, J. J. and M. R. Servedio. 2000. Species delimitation in systematics: inferring diagnostic differences between species. Proceedings of the Royal Society B: Biological Sciences 267: 631-636.

Wiley, E. O. 1978. The evolutionary species concept reconsidered. Systematic Zoology 27: 17-26.

Williams, E. E. 1963. Studies on South American Anoles. Bulletin of the Museum of Comparative Zoology 129: 463-480.

Williams, E. E. 1975. South American Anolis: Anolis parilis, new species, near A. mirus Williams. Breviora 434: $1-8$.

Williams, E. E. 1976. South American anoles: the species groups. Papéis Avulsos de Zoologia, São Paulo 29: 259-268.

Williams, E. E., H. Rand, A. S. Rand, and R. J. O’Hara. 1995. A computer approach to the comparison and identification of species in difficult taxonomic groups. Breviora 502: 1-47. 